\title{
Sex Determination Using Inion-Opistocranium-Asterion (IOA) Triangle in Nigerians' Skulls
}

\author{
C. N. Orish, B. C. Didia, and H. B. Fawehinmi \\ Department of Anatomy, Faculty of Basic Medical Sciences, University of Port-Harcourt, PMB 5323, Choba, \\ Port Harcourt, Rivers State, Nigeria
}

Correspondence should be addressed to C. N. Orish; chinnaorish@yahoo.com

Received 8 February 2014; Revised 17 April 2014; Accepted 24 April 2014; Published 18 May 2014

Academic Editor: David Tai Wai Yew

Copyright (C) 2014 C. N. Orish et al. This is an open access article distributed under the Creative Commons Attribution License, which permits unrestricted use, distribution, and reproduction in any medium, provided the original work is properly cited.

Background. Determination of sex is an important concern to the forensic anthropologists as it is critical for individual identification. This study has investigated the existence of sexual dimorphism in the dimensions and the area of the IOA triangle. Methods. A total of 100 adult dry skulls, (78 males; 22 females) from departments of anatomy in Nigerian universities were used for this study. Automatic digital calliper was used for the measurement. Coefficient of variation, correlation, linear regression, percentiles, and sexual dimorphism ratio were computed from the IOA triangle measurements. The IOA triangle area was compared between sexes. Results. The male parameters were significantly $(P<0.05)$ higher than female parameters. The left opistocranium-asterion length was $71.09 \pm 0.56$ and $61.68 \pm 3.35 \mathrm{~mm}$ and the right opistocranium-asterion length was $69.73 \pm 0.49$ and $60.92 \pm 2.10 \mathrm{~mm}$ for male and female, respectively. A total area of IOA triangle of $1938.88 \mathrm{~mm}^{2}$ and $1305.68 \mathrm{~mm}^{2}$ for male and female, respectively, was calculated. The left IOA indices were $46.42 \%$ and $37.40 \%$ in males and females, respectively, while the right IOA indices for males and females were $47.19 \%$ and $38.87 \%$, respectively. Conclusion. The anthropometry of inion-opistocraniumasterion IOA triangle can be a guide in gender determination of unknown individuals.

\section{Introduction}

The existence of sexual dimorphism in human skeletons and its importance in medicolegal investigations have long been acknowledged. The skull is probably the most studied bone in that context. Krogman and Iscan [1] stated that sex assessment in a collection of 750 skeletons was possible, with levels of reliability of $100 \%$ when the entire skeleton was present, $92 \%$ using the skull alone, and $98 \%$ when combining the pelvis and skull. Even though several postcranial elements have more recently proved to be more effective sex predictors [2], the skull remains among the most dimorphic parts of the skeleton. Saavedra de Paiva and Segre [3] introduced an easy technique for sex determination starting from the temporal bone. The technique is based on the triangular area calculation obtained between these points: porion, mastoidale, and asterion, measured from xerographic copy of skulls. They found significant differences in the area between the right and left mastoid triangle when comparing male and female skulls, but owing to the asymmetries present in the skulls, it is recommended to observe the value of the total area (adding right and left sides), which was also significant, so that when it is higher than or equal to $1447.40 \mathrm{~mm}^{2}$, the skull is diagnosed as male skull, and a value near to $1260.36 \mathrm{~mm}^{2}$ or less is indicative of female skull [3]. Some of the earlier studies following this approach include those on Europeans $[4,5]$, Americans [6], South Africans [6-9], Japanese [10, 11], and Chinese [12] and had earlier researched on skull.

Despite the increase in research on sex prediction using craniofacial characteristics worldwide, information on such parameters is sparse in Nigerian population.

The aim of this study is to develop a sex determination technique using a triangle defined by these points: inion, opistocranium, and asterion; the union of these points determines the IOA triangle.

\section{Materials and Method}

A total of 100 adult dry skulls (78 males and 22 females), free from damage and deformity and fully ossified from 
TABLE 1: Maximum, minimum, geometric mean, coefficient of variation, mean,and SEM of inion-opistocranium length, left inion-asterion length (bracket) ${ }^{\#}$, and right inion-asterion length [parentheses] ${ }^{\infty}(\mathrm{mm})$.

\begin{tabular}{|c|c|c|c|c|c|}
\hline Sex & Mean \pm SEM & Coefficient of variation & Geometric mean & Maximum & Minimum \\
\hline \multirow{3}{*}{ Male (mm) } & $30.03 \pm 0.50$ & $16.01 \%$ & 29.67 & 46.59 & 22.21 \\
\hline & $(64.69 \pm 0.40)^{\#}$ & $(5.91 \%)^{\#}$ & $(64.58)^{\#}$ & $(75.49)^{\#}$ & $(56.94)^{\#}$ \\
\hline & {$[63.64 \pm 0.40]^{\infty}$} & {$[6.03 \%]^{\infty}$} & {$[63.53]^{\infty}$} & {$[74.17]^{\infty}$} & {$[55.06]^{\infty}$} \\
\hline \multirow{3}{*}{ Female $(\mathrm{mm})$} & $22.34 \pm 2.10^{*}$ & $29.68 \%$ & 21.47 & 32.22 & 14.10 \\
\hline & $\left(59.74 \pm 0.65^{*}\right)^{\#}$ & $(3.47 \%)^{\#}$ & $(59.70)^{\#}$ & $(61.32)^{\#}$ & $(54.63)^{\#}$ \\
\hline & {$\left[57.48 \pm 1.56^{*}\right]^{\infty}$} & {$[8.59 \%]^{\infty}$} & {$[57.27]^{\infty}$} & {$[61.22]^{\infty}$} & {$[47.76]^{\infty}$} \\
\hline
\end{tabular}

${ }^{*} P<0.05$ statistically significant from male.

Numbers in brackets represent left inion-asterion length ${ }^{\#}$ and numbers in parentheses represent right inion-asterion length [parentheses] ${ }^{\infty}$ (mm).

TABLE 2: Maximum, minimum, geometric mean, coefficient of variation, mean, and SEM of left opistocranium-asterion length and right opistocranium-asterion length $(\mathrm{mm})$.

\begin{tabular}{|c|c|c|c|c|c|}
\hline Sex & Mean \pm SEM & Coefficient of variation & Geometric mean & Maximum & Minimum \\
\hline Male (mm) & $\begin{array}{c}71.09 \pm 0.56 \\
(69.73 \pm 0.49)^{\#}\end{array}$ & $\begin{array}{c}7.50 \% \\
(6.67 \%)\end{array}$ & $\begin{array}{l}70.88 \\
(69.58)\end{array}$ & $\begin{array}{c}82.95 \\
(81.79)\end{array}$ & $\begin{array}{c}52.51 \\
(57.71)\end{array}$ \\
\hline Female $(\mathrm{mm})$ & $\begin{array}{c}61.68 \pm 3.35^{*} \\
\left(60.92 \pm 2.10^{*}\right)^{\#}\end{array}$ & $\begin{array}{c}16.28 \% \\
(14.53 \%)\end{array}$ & $\begin{array}{l}60.90 \\
(60.35)\end{array}$ & $\begin{array}{c}74.10 \\
(75.00)\end{array}$ & $\begin{array}{c}44.00 \\
(48.00)\end{array}$ \\
\hline
\end{tabular}

${ }^{*} P<0.05$ statistically significant. Numbers in brackets represent right opistocranium-asterion length $(\mathrm{mm})^{\#}$.

departments of anatomy in Nigerian universities, were used for this study. A digital caliper with a precision of $0.01 \mathrm{~mm}$ (Mitutoyo) and marker were used to measure the following length parameters: opistocranium-asterion, opistocraniuminion, and inion-asterion. The skull was kept with Norma occipitalis facing the observer.

Inion. Inion is the most prominent point in the posterior aspect of the occipital calvarium occurring at the intersection of the left and right superior nuchal lines.

Opistocranium. Opistocranium is the most posteriorly protruding point on the back of the skull, located in the midsagittal plane.

Asterion. Asterion is the meeting point of the lambdoid, occipitomastoid, and parietomastoid sutures or the point where the temporal, parietal, and occipital bones meet.

The union of these points determines the IOA triangle (Figure 1).

Data was anaylzed with Graph Pad Prism 5.03. The mean, standard deviation, standard error of mean, maximum, minimum, geometric mean, coefficient of variation, correlation, linear regression, percentiles, and sexual dimorphism ratio were computed. The IOA triangle area and IOA index were calculated and compared between males and females:

$$
\text { IOA INDEX }=\frac{\text { Inion-opistocranium }}{\text { Inion-asterion }} \times 100
$$

The results were shown in Tables 1 and 2 showing the measurements data of male and female skulls. Table 3 shows the percentiles of right and left inion-opistocranium, right and left inion-asterion length, and the IOA index in males and females. Table 4 shows the IOA index. Table 5 shows the area of IOA triangle. Table 6 shows sexual dimorphism ratio of

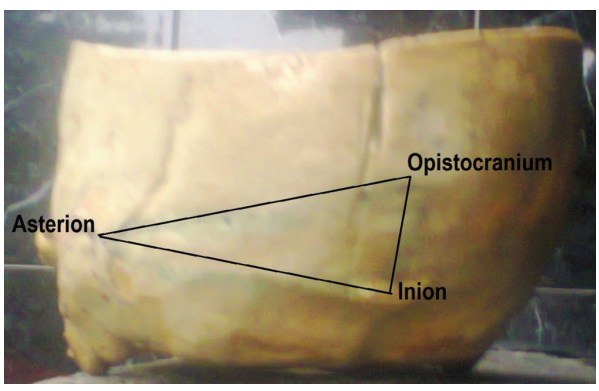

FIGURE 1: The area of the demarcated triangle as in Figure 1 was used for the results.

the measurements inion-opistocranium, inion-asterion, and opistocranium-asterion.

The male/female ratios for the mean measurements were greater than unity, indicating that the male crania were larger in all linear dimensions than female crania. From the sexual dimorphism ratios calculated for recent Nigerian population inion-opisthocranion had the highest (1.34), while inionasterion had the least (1.09) and opisthocranion-asterion had 1.15 .

Correlation of craniometric parameters of Nigerian male and female populations is shown in Table 7. Male opistocranium-asterion left versus right had positive significant correlation, while inion-asterion left versus right had positive correlation. In the female population, opistocranium-asterion left versus right and inion-asterion left versus right had positive significant correlation.

Figure 2 is a scatter plot of the linear relationship between left and right male inion-asterion length. There was positive correlation between the left and right; hence, the fit line sloped upward. Figure 3 shows a scatter plot of the linear 
TABLE 3: Percentiles of inion-opistocranium, right and left ${ }^{\#}$ inion-asterion length and right and left ${ }^{\#}$ IOA index in males and females.

\begin{tabular}{|c|c|c|c|c|c|c|c|}
\hline & Sex & 10th & 25 th & 50th (Median) & 75 th & 90th & Normality test \\
\hline \multirow{2}{*}{ Inion-opistocranium length } & Male & 24.43 & 26.66 & 29.83 & 32.56 & 34.88 & $<0.0001^{*}$ \\
\hline & Female & 14.21 & 15.83 & 21.16 & 26.67 & 32.10 & 0.4179 \\
\hline \multirow{4}{*}{ Inion-asterion length } & \multirow{2}{*}{ Male } & 58.71 & 61.11 & 63.39 & 65.93 & 68.54 & 0.4629 \\
\hline & & {$[60.15]^{\#}$} & [61.83] & [64.48] & {$[67.27]$} & [70.09] & {$[0.1111]$} \\
\hline & \multirow{2}{*}{ Female } & 48.01 & 53.25 & 59.84 & 61.11 & 61.21 & 0.1598 \\
\hline & & {$[55.03]^{\#}$} & [58.95] & {$[60.63]$} & {$[61.14]$} & [61.31] & {$\left[0.0027^{*}\right]$} \\
\hline \multirow{2}{*}{ Right/[Left $]^{\#}$ IOA index } & \multirow{2}{*}{ Male } & 39.24 & 41.95 & 46.06 & 52.07 & 56.46 & 0.0002 \\
\hline & & {$[36.22]^{\#}$} & [41.54] & {$[45.52]$} & [50.32] & {$[56.66]$} & {$\left[0.0001^{*}\right]$} \\
\hline
\end{tabular}

${ }^{*} P<0.05$ statistically significant from male.

${ }^{\#}$ Data in parenthese represent Percentiles of left length, inion-opistocranium, and left inion-asterion; left IOA index.

TABLE 4: IOA index.

\begin{tabular}{lccc}
\hline Sex & $\begin{array}{c}\text { Left IOA index } \\
(\%)\end{array}$ & $\begin{array}{c}\text { Right IOA index } \\
(\%)\end{array}$ & $\begin{array}{c}\text { Average IOA index } \\
(\%)\end{array}$ \\
\hline Male & 46.42 & 47.19 & 46.81 \\
Female & 37.40 & 38.87 & 38.14 \\
\hline
\end{tabular}

TABLE 5: Area of IOA triangle $\mathrm{mm}^{2}$.

\begin{tabular}{lccc}
\hline & Left & Right & Total area \\
\hline Male & 972.17 & 966.71 & 1938.88 \\
Female & $664.04^{*}$ & $641.64^{*}$ & $1305.68^{*}$ \\
\hline
\end{tabular}

${ }^{*} P<0.05$ statistically significant from male.

relationship between left and right male opistocraniumasterion. There was positive correlation between the left and right; hence, the fit line sloped upward. Figure 4 shows a scatter plot of the linear relationship between left and right female opistocranium-asterion. There was positive correlation between the left and right; hence, the fit line sloped upward. Figure 5 shows a scatter plot of the linear relationship between left and right female inion-asterion length. There was positive correlation between the left and right; hence, the fit line sloped upward.

\section{Discussion}

Accurate determination of sex from the human skull is of great importance to osteologists and the forensic anthropologists as it is critical for individual identification. It eliminates approximately $50 \%$ of the population from further consideration in cases of missing persons. Moreover, many additional individualization criteria are sex specific [1-13]. The morphological differences between both sexes can be the result of multiple factors such as genetic factors, for example, a relative fixed racial genome, but the phenotypic expression is modified by multiple factors such as local customs and environmental factors affecting growth and development (nutrition, physical activity, life-style, health, etc.). The only constants in this complex equation are the biological sex controlled by sex chromosomes and genetic and/or racial heritage $[1,14,15]$. Studies on sexual dimorphism are based

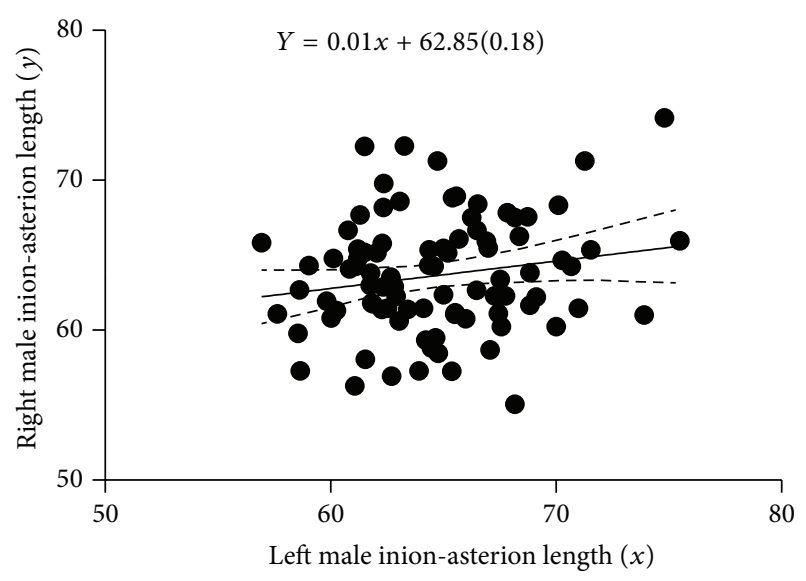

FIGURE 2: Linear regression graph of male left and right inionasterion length.

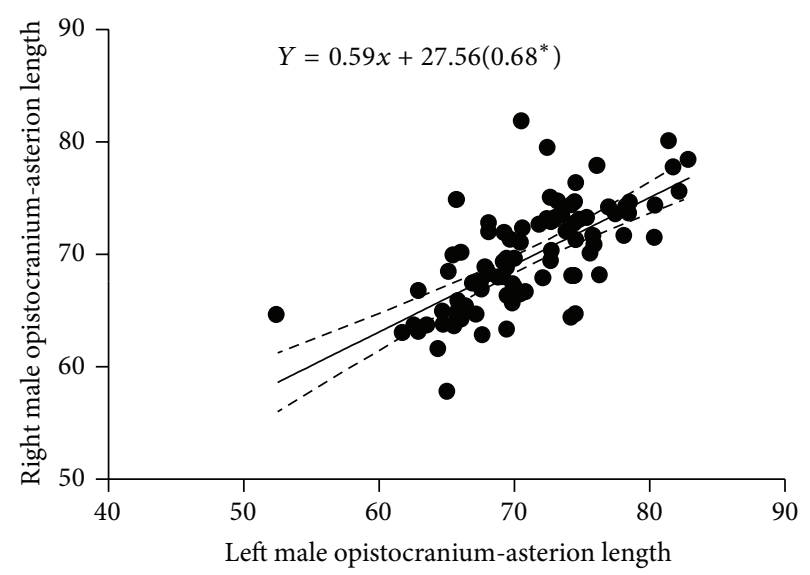

Figure 3: Linear regression graph of male left and right opistocranium-asterion length.

on three primary biological differences between males and females, which are size, body proportions, and architectural differences [16]. Males are generally more robust than females as they have generally more muscle mass. The weight of the axial skeleton of the male is relatively and absolutely heavier than that of the female by about $8 \%$ [16]. 
TABLE 6: Sexual dimorphism ratio.

\begin{tabular}{lccc}
\hline Parameters & Male mean $(\mathrm{mm})$ & Female mean $(\mathrm{mm})$ & \multicolumn{2}{c}{$\begin{array}{c}\text { Sexual dimorphism ratio }=\text { M. } \\
\text { mean/F. mean }\end{array}$} \\
\hline Inion-opistocranium & 30.03 & 22.34 & 1.34 \\
Inion-asterion & 64.16 & 58.61 & 1.09 \\
Opistocranium-asterion & 70.41 & 61.30 & 1.15 \\
\hline
\end{tabular}

TABLE 7: Correlation of craniometric parameters of Nigerian male and female populations.

\begin{tabular}{lc}
\hline $\begin{array}{l}\text { Male craniometric parameter } \\
(x \text { versus } y)\end{array}$ & Regression (correlation, $r)$ \\
$\begin{array}{l}\text { Opistocranium-asterion left } \\
\text { versus right }\end{array}$ & $Y=0.59 x+27.56\left(0.68^{*}\right)$ \\
$\begin{array}{l}\text { Inion-asterion left versus right } \\
\text { Female craniometric parameter } \\
(x \text { versus } y)\end{array}$ & $Y=0.01 x+62.85(0.18)$ \\
$\begin{array}{l}\text { Opistocranium-asterion left } \\
\text { versus right }\end{array}$ & $Y=0.77 x+13.12\left(0.9^{*}\right)$ \\
Inion-asterion left versus right & $Y=1.601 x-37.84\left(0.67^{*}\right)$ \\
\hline
\end{tabular}

${ }^{*}$ Stastical significance.

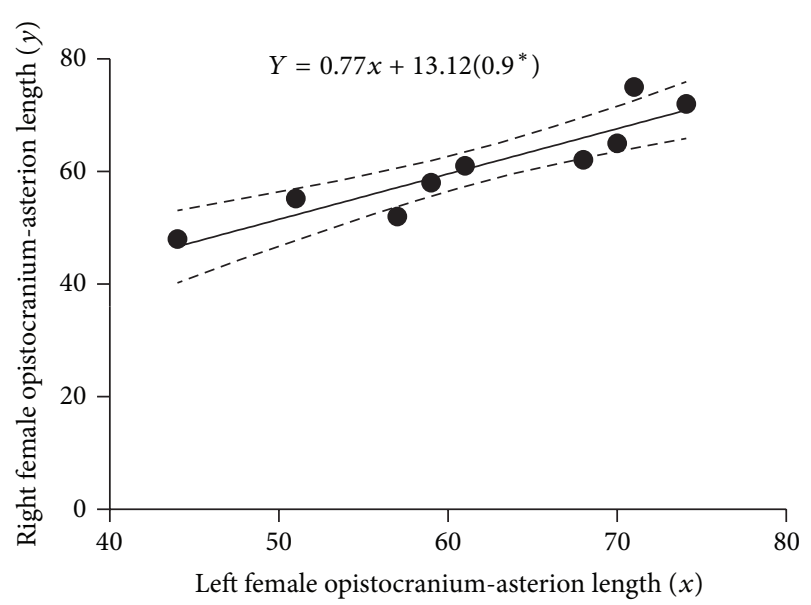

Figure 4: Linear regression graph of female and right opistocranium-asterion length.

This might be the first report on sex determination technique using IOA triangle as we are not aware of any previous data. However, in other related studies, $[8,17]$ showed that male parameters were higher than female and statistically significant at $P<0.05$ which correlates well with the present findings. The length of male inion-opistocranium was significantly different from the female. The length of left and right male inion-asterion was significantly higher than that of the female. There was a significant difference between male left and right opistocranium-asterion from female.

Area of IOA triangle of male was found to be significantly higher than that of female. Although there seems to be no previous report on this parameter, our result on IOA triangle seems to agree with the findings of $[3,18]$ on mastoid triangle

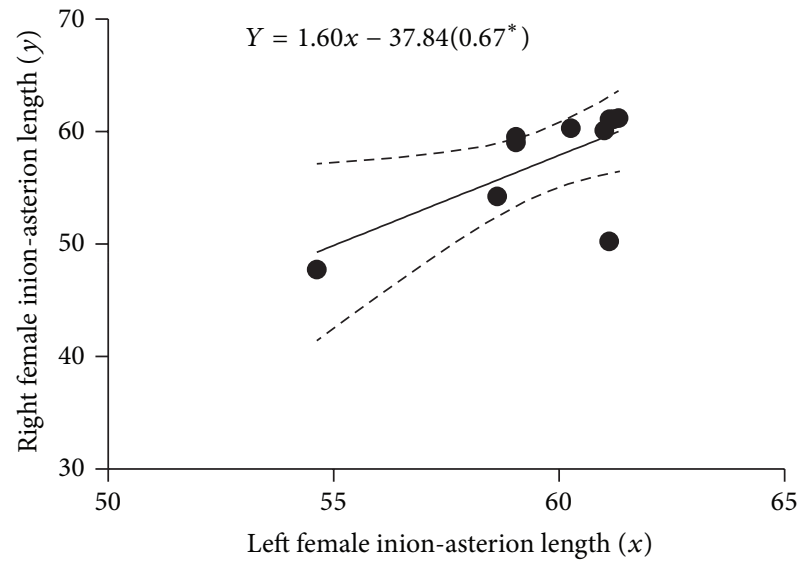

FIgURE 5: Linear regression graph of female left and right inionasterion length.

of Caucasians skulls using Heron's report that included that the total area is higher in male than in female.

Ahmed et al. [19] reported that sexual dimorphism ratio (male/female ratios) for the mean measurements was greater than unity, indicating that the male crania were larger in all linear dimensions than female crania. From the sexual dimorphism ratios calculated for Sudanese population, the ratios were Basion-prosthion, and Basion-bregma (1.05), Bregmalambda (1.02), Basion-nasion (1.04), Basion-prosthion (1.06), and Nasion-bregma (1.04). These data are similar to the present study that has presented sexual dimorphism ratio is greater than unity, indicating that the male crania were larger in all linear dimensions than female crania.

Hitherto information is scanty on the mathematical models of these craniometric parameters [20]. A positive regression coefficient indicates a positive relationship between two variables and from the graph the fit line sloped upward as in male and female opistocranium-asterion left versus right and inion-asterion left versus right. The present result showed that male opistocranium-asterion left versus right had positive significant correlation, while inion-asterion left versus right had positive correlation, whereas female opistocranium-asterion left versus right and inion-asterion left versus right had positive significant correlation. This study has also documented that the percentiles of right and left inion-opistocranium, right and left inion-asterion length left IOA index progressively increased in values from 10th percentiles to 90 th in both sexes with male values higher than female values except female right IOA index which showed a higher value than that of male. The male IOA index was higher than that of female. 
Taken together the present research showed high level of sexual dimorphism and will be of immense help to forensic expert. Further research will validate these findings.

\section{Conflict of Interests}

The authors declare that there is no conflict of interests regarding the publication of this paper.

\section{References}

[1] W. M. Krogman and M. Y. Iscan, The Human Skeleton in Forensic Medicine, Charles C.Thomas, Springfield, Ill, USA, 1986.

[2] H. de Villiers, "Sexual dimorphism of the skull of the South African Bantu-speaking Negro," South African Journal of Science, vol. 64, pp. 118-124, 1968.

[3] L. A. Saavedra de Paiva and M. Segre, "Sexing the human skull through the mastoid process," Revista do Hospital das Clinicas, vol. 58, no. 1, pp. 15-20, 2003.

[4] G. Boulinier, "La détermination du sexe des crânes humains à l'aide des fonctions discriminantes," Bulletins et Mémoires de la Société d'Anthropologie de Paris, vol. 3, no. 3-4, pp. 301-316, 1968.

[5] E. Defrise-Gussenhoven, "A masculinity-femininty scale based on a discriminant function," Acta Genetica et Statistica Medica, vol. 16, no. 2, pp. 198-208, 1966.

[6] E. Giles and O. Elliot, "Sex determination by discriminant function analysis of crania," American Journal of Physical Anthropology, vol. 21, pp. 53-68, 1963.

[7] J. A. Keen, "A study of the differences between male and female skulls," American Journal of Physical Anthropology, vol. 8, no. 1, pp. 65-79, 1950.

[8] M. Steyn and M. Y. Işcan, "Sexual dimorphism in the crania and mandibles of South African whites," Forensic Science International, vol. 98, no. 1-2, pp. 9-16, 1998.

[9] M. Y. Işcan and M. Steyn, "Craniometric determination of population affinity in South Africans," International Journal of Legal Medicine, vol. 112, no. 2, pp. 91-97, 1999.

[10] K. Hanihara, "Sex diagnosis of Japanese skulls and scapulae by means of discriminant function," Journal of Anthropological Society of Nippon, vol. 67, pp. 21-27, 1959.

[11] M. Y. Iscan, M. Yoshino, and S. Kato, "Sexual dimorphism in modern Japanese crania," American Journal of Human Biology, vol. 7, pp. 459-464, 1995.

[12] M. Y. Iscan and S. Ding, Sexual Dimorphism in the Chinese Cranium, International Association of Craniofacial Identification, Boca Raton, Fla, USA, 1995.

[13] D. R. Brothwell, Digging Up Bones: The Excavation, Treatment and Study of Human Skeletal Remains, British Museum: Oxford University Press, 3rd edition, 1981.

[14] S. Mays and S. Cox, "Sex determination in skeletal remains," in Human Osteology in Archaeology and Forensic Science, S. Mays and M. Cox, Eds., Cambridge University, Cambridge, UK, 2000.

[15] L. L. Klepiner, Fundamentals of Forensic Anthropology, John Wiley \& Sons, Hoboken, NJ, USA, 2006.

[16] L. E. St. Hoymes and M. Y. Iscan, "Determination of sex and race: accuracy and assumptions," in Reconstruction of Life from the Skeleton, M. Y. Iscan and K. A. R. Kennedy, Eds., pp. 53-94, Wiley-Liss, New York, NY, USA, 1989.
[17] A. G. Deshmukh and D. B. Devershi, "Comparison of cranial sex determination by univariate and multivariate analysis," Journal of the Anatomical Society of India, vol. 55, no. 2, pp. 4851, 2006.

[18] G. I. C. Suazo, M. D. Zavando, and R. L. Smith, "Determinación del sexo usando mediciones en el proceso mastoides en cráneos brasileños," International Journal of Morphology, vol. 26, no. 4, pp. 941-944, 2008.

[19] A. A. Ahmed, H. A. Mohammed, and M. A. Hassan, "Sex determination from cranial measurements in recent northern Sudanese," Khartoum Medical Journal, vol. 4, no. 1, pp. 539-547, 2011.

[20] S. Rooppakhun, N. Chantarapanich, and K. Sitthiseripratip, "Advanced medical imaging and reverse engineering technologies in craniometric study," in Forensic Medicine-From Old Problems to New Challenges, D. N. Vieira, Ed., pp. 307-326, InTech, 2011. 

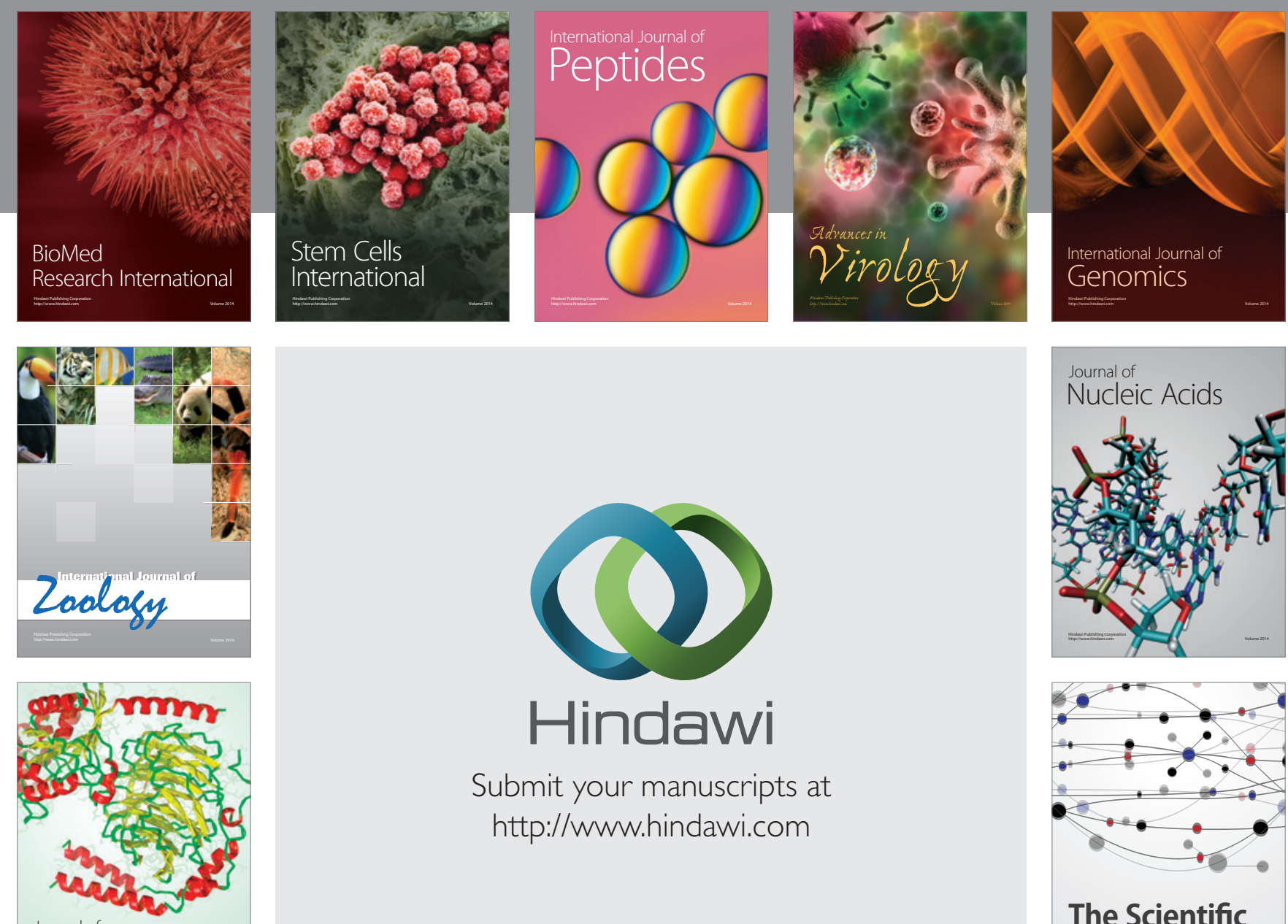

Submit your manuscripts at

http://www.hindawi.com

Journal of
Signal Transduction
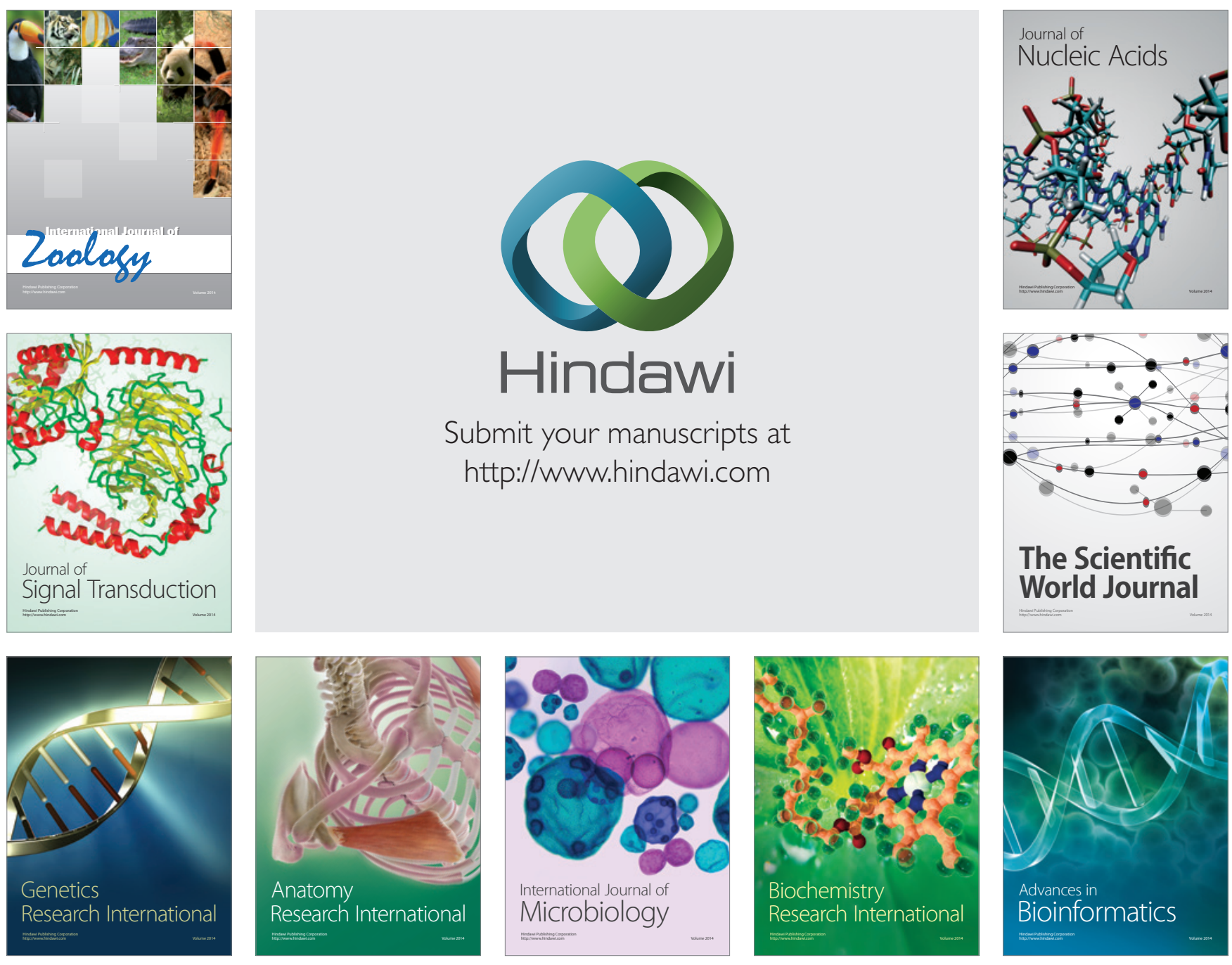

The Scientific World Journal
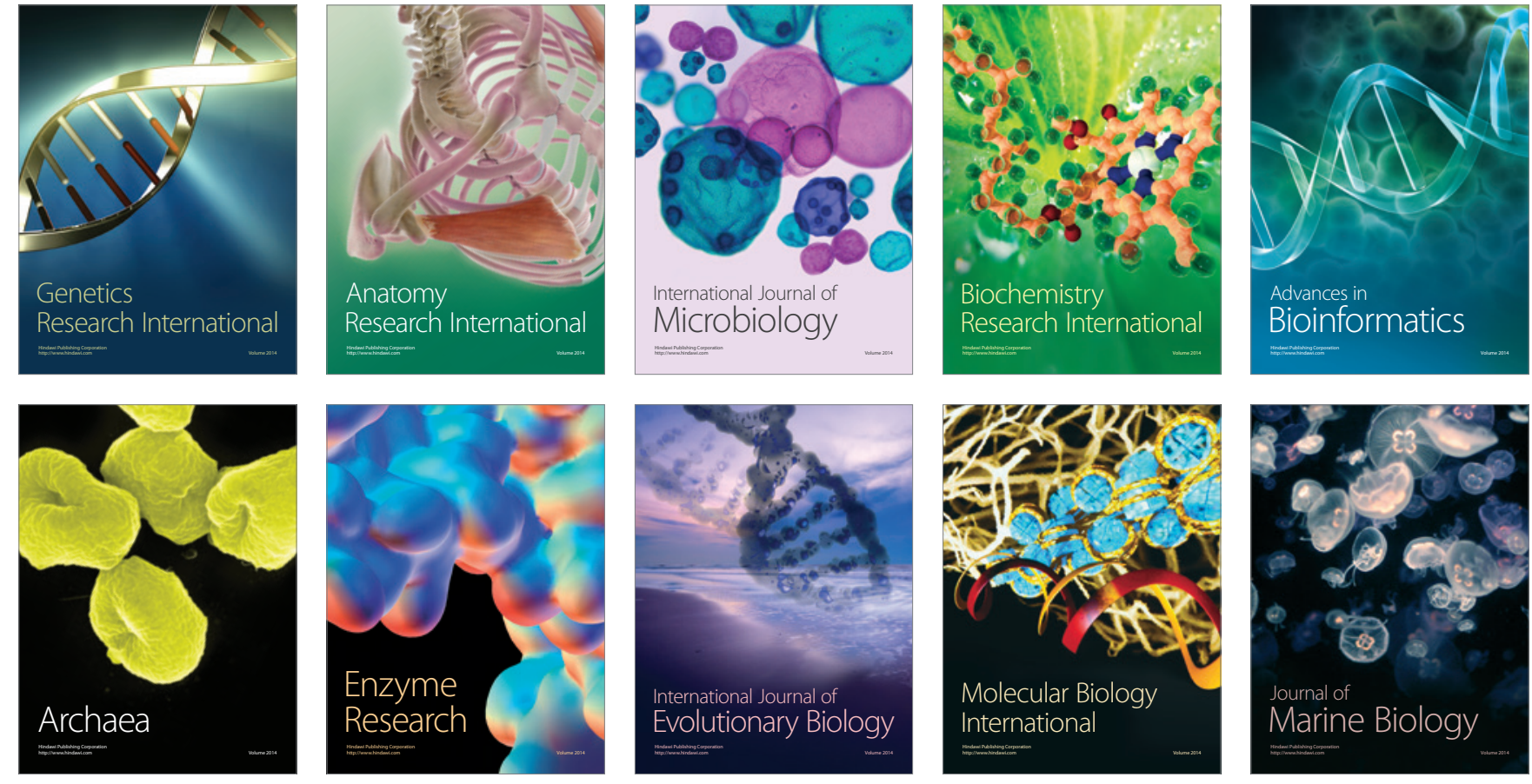